\title{
22. NEOGENE COCCOLITH STRATIGRAPHY, GULF OF CALIFORNIA, DEEP SEA DRILLING PROJECT LEG 65 $^{1}$
}

\author{
John G. Hattner, ${ }^{2}$ Antarctic Marine Geology Facility, Department of Geology, \\ Florida State University, Tallahassee, Florida
}

\section{INTRODUCTION}

Leg 65 of the Deep Sea Drilling Project (DSDP) recovered cores at four drilling sites: $482,483,484$, and 485 (Fig. 1). Because the prime objective of the leg was to drill a deep hole into near-zero-age crust adjacent to the crest of the fast-spreading East Pacific Rise, only Neogene-age sediments were recovered. At Site 482 , seven holes were drilled; the oldest sediments recovered contained Martini's (1971) Zone NN20/21 (indicated by the presence of Emiliania huxleyi and Gephyrocapsa oceanica and the absence of Pseudoemiliania lacunosa). Because of dilution of the turbiditic sediments, a differentiation of Zones NN20/21 was not possible. The oldest sediments recovered at Site 483 were late Pliocene (Discoaster brouweri, Zone NN18). At Sites 484 and 485 we encountered sediments of Zone NN19 ( $P$. lacunosa Zone) in the lowest recovered sedimentary intervals. The positions of zonal boundaries in the sites are shown in Figure 2. The coccolith species encountered are listed in Table 1 and discussed below for each site.

\section{COCCOLITH STRATIGRAPHY}

\section{Site $\mathbf{4 8 2}$}

Site 482 is located approximately $12 \mathrm{~km}$ east of the axis of the East Pacific Rise. The sediment column is about 137 meters above the uppermost basalt and consists of Quaternary-age hemipelagic clay. Additional sediments encountered within the basalt sequence are often indurated and dolomitized, causing variations in the state of coccolith preservation.

The sediments at Site 482 belong to the combined Quaternary NN20/21 Zones of Martini (1971). Because of high sedimentation rates, extremely varied preservation, and the turbiditic nature of the sediments recovered, however, Zones NN20 and NN21 could not be differentiated. Persistent reworking, poor recovery within certain intervals (especially within the basalts), and drilling disturbance made the construction of a species range chart impractical.

\section{Site 483}

Site 483 , located about $52 \mathrm{~km}$ west of the crest of the East Pacific Rise, lies in a sediment pond about $81 \mathrm{~km}$ wide. Approximately 110 meters of sediment were re-

\footnotetext{
${ }^{1}$ Lewis, B. T. R., Robinson, P., et al., Init. Repts. DSDP, 65: Washington (U.S. Govt. Printing Office)

2 Present address: Chevron U.S.A., Inc., P.O. Box 51743, Lafayette, La.
}

covered above basement, of which the interval from 0 to 33 meters was assigned to the combined NN20/21 Zone (Martini, 1971). The uppermost 18 meters of this interval contained common reworked nannofossils as would be expected in turbiditic sediments. Reworked nannofossils included Cyclococcolithus macintyrei, Discoaster asymmetricus, and Pseudoemiliania lacunosa.

The interval from 33 to 110 meters was assigned to Zone NN19 (Martini, 1971). The interval just above basement (105-110 m) belongs to the Cyclococcolithus macintyrei Zone of Gartner (1977).

The first basalt recovered was emplaced during the Olduvai Event, and the first sediment recovered within the basalt belongs to the Pliocene Zone NN18 (Martini, 1971). This zone (the Discoaster brouweri Zone) was the oldest recognizable coccolith zone sampled during Leg 65 . Because of poor preservation and the scarcity of coccoliths within the sediments intercalated in the basalt complex, no further or additional zonal assignments were possible.

\section{Site 484}

Site 484 was drilled to the north of the Tamayo Fracture Zone on top of a basement high interpreted as a magnetic "diapir" (Fig. 1). From Hole 484A we recovered 59.5 meters of sediment, of which the interval from 0 to 45 meters was assigned to the combined NN20/21 Zones of late Quaternary age. The sediments below 45 meters were assigned to Zone NN19 (Martini, 1976). The uppermost 9 meters of the section contained a strongly reworked assemblage containing fossils of Pliocene to Quaternary age. These included Pseudoemiliania lacunosa, Discoaster brouweri, Gephyrocapsa oceanica, Helicopontosphaera sellii, $H$. wallichi, Cyclococcolithina macintyrei, Coccolithus pelagicus, and Emiliania huxleyi.

\section{Site 485}

Site 485 lies slightly to the east of Site 482 ; we recovered 153 meters of sediment above the uppermost basalt. The sediment from 0 to 36 meters was assigned to the combined Quaternary NN20/21 Zones, and the sediments from 36 meters down to and within the basalt sequence were assigned to Zone NN19. The sediments intercalated within the basalt are believed to be no older than 1.22 m.y., based on the absence of Helicopontosphaera sellii (Gartner, 1977). This determination is somewhat tenuous since sediment recovery and preservation within the basalt were poor, and it is not likely that one could detect the presence of $H$. sellii. 




Figure 1. Locations of sites drilled on Leg 65. 
LEG 65

CALCAREOUS

NANNOFOSSIL

BIOSTRATIGRAPHY

Marker Horizons:

(1) P. lacunosa -0.44 m.y.

(2) C. macintyrei- 1.51 m.y.

(3) D. brouweri -1.65 m.y.
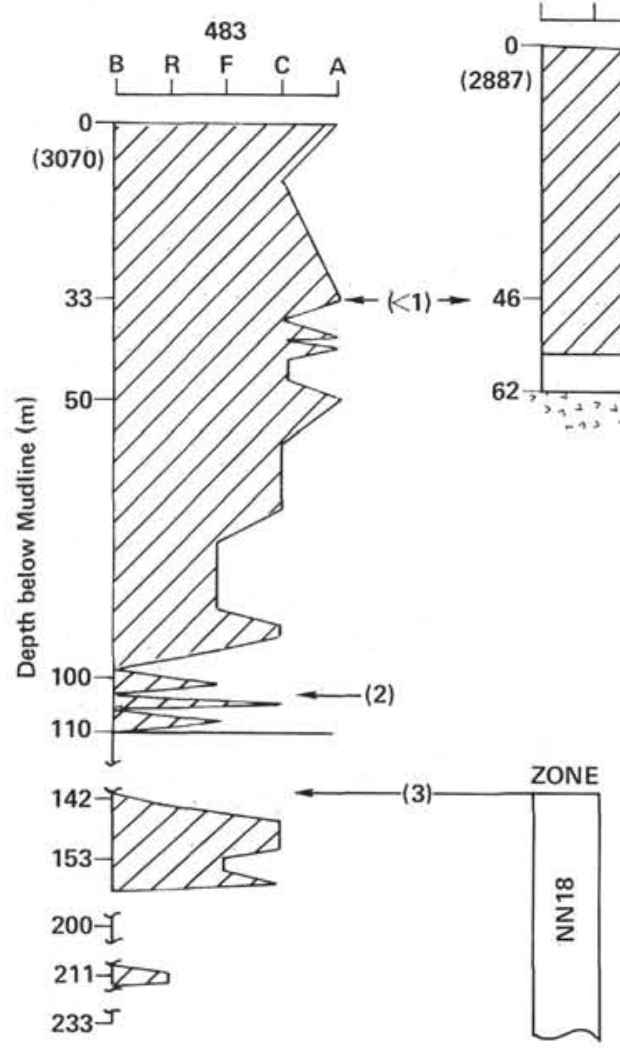
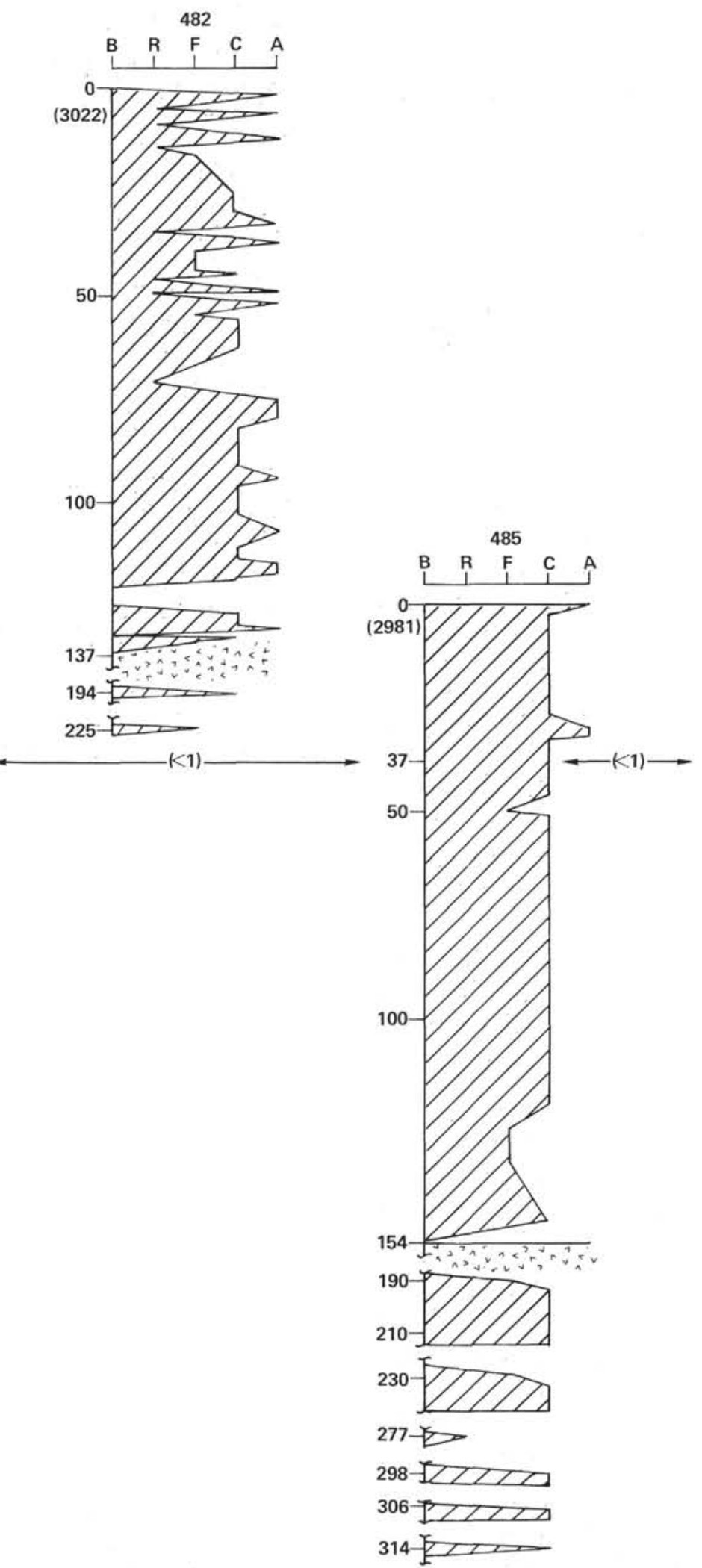

Figure 2. Calcareous nannofossil biostratigraphy for Sites 482, 483, 484, and 485 . Zones after Martini (1971). (B, R, F, C, and A correspond to barren, rare, frequent, common, and abundant, respectively. Columns adjusted to show positions relative to the boundary between Zones NN20/21 and NN19. Depths in parentheses indicate depth to mudline. Ages given for marker horizons represent highest occurrence.) 
Table 1. Neogene coccolith species list, Leg $65 .^{\mathrm{a}}$

\begin{tabular}{l}
\hline \multicolumn{1}{c}{ Species } \\
\hline Discoaster asymmetricus Gartner \\
Braaudosphaera bigelowi (Gran and Braarud) \\
D. brouweri Tan Sin Hok \\
Gephyrocapsa caribbeanica Kamptner \\
Ceratolithus cristatus (Lohmann) \\
Emiliania huxleyi (Lohmann) \\
Helicopontosphaera kamptneri (Hay and Mohler) \\
Pseudoemiliania lacunosa (Kamptner) \\
Cycloccolithina leptoporus (Murray and Blackman) \\
C. macintyrei (Bukry and Bramlette) \\
Gephyrocapsa oceanica Kamptner \\
Coccolithus pelagicus (Wallich) \\
Ceratolithus rugosus Bukry and Bramlette \\
Rhabdosphaera sp. \\
Helicopontosphaera sellii Bukry and Bramlette \\
D. surculus Martini and Bramlette \\
Ceratolithus telesmus Norris \\
Helicopontosphaera wallichi (Lohmann) \\
\hline
\end{tabular}

a Bibliographic references for these taxa are presented in Loeblich and Tappan (1966, 1968, 1969, 1970a, 1970b, 1971, 1973).

\section{CONCLUSIONS}

Although poor preservation, high sedimentation rates, and drilling disturbance precluded the establishment of a detailed coccolith stratigraphy for the mouth of the Gulf of California on Leg 65, the coccoliths recovered and their positions in the columns are basically consis- tent with the ages of the sites determined from magnetic anomalies. With the development and routine deployment of the hydraulic piston corer, it is hoped that this stratigraphy might be reconstructed in detail should the Glomar Challenger return to the Gulf of California in the future.

\section{ACKNOWLEDGMENTS}

I would like to thank Drs. S. W. Wise (Florida State University, Tallahassee) and F. H. Wind (Texaco, Inc., Los Angeles) for reviewing this manuscript. I would also like to thank the Deep Sea Drilling Project for the opportunity to participate on Leg 65 .

\section{REFERENCES}

Gartner, S., 1977. Calcareous nannofossil biostratigraphy and revised zonation of the Pleistocene. Mar. Micropaleont., 2:1-25.

Loeblich, Jr., A. R., and Tappan, H., 1963. Type fixation and validation of certain calcareous nannoplankton genera. Proc. Biol. Soc. Wash., 76:191-196.

1966. Annotated index and bibliography of the calcareous nannoplankton. Phycologia, 5:81-216.

1968. Annotated index and bibliography of the calcareous nannoplankton II. J. Paleont., 42:584-598.

, 1969. Annotated index and bibliography of the calcareous nannoplankton III: J. Paleont., 43:568-588. , 1970a. Annotated index and bibliography of the calcareous nannoplankton IV: J. Paleont., 44:558-574.

,1970b. Annotated index and bibliography of the calcareous nannoplankton V. Phycologia, 9:157-174.

1971. Annotated index and bibliography of the calcareous nannoplankton VI. Phycologia, 10:315-339.

1973. Annotated index and bibliography of the calcareous nannoplankton VIII. J. Paleont., 47:715-759.

Martini, E., 1971. Standard Tertiary calcareous nannoplankton zonation. In Farinacci, A. (Ed.), Second Plankt. Conf. Proc., Roma, 1970, pp. 739-785. 